\title{
THE IMPORTANCE OF CELLULAR CHANGES IN THE CONJUNCTIVA OF PATIENTS WITH UVEITIC GLAUCOMA UNDERGOING TRABECULECTOMY
}

\author{
DAVID C. BROADWAY, A. KEITH BATES, SUSAN L. LIGHTMAN, IAN GRIERSON and \\ ROGER A. HITCHINGS \\ London
}

\begin{abstract}
SUMMARY
The results of trabeculectomy in patients with glaucoma secondary to uveitis are poor, but the exact cause of this remains unknown. Therefore, a study was undertaken to determine differences between conjunctiva from patients with glaucoma secondary to uveitis and that from patients with primary open angle glaucoma. Conjunctival biopsies from three patient groups were quantitatively analysed by light microscopy. Group A consisted of 10 patients with glaucoma secondary to uveitis who, prior to surgery, had been treated with topical steroids and topical beta-blocker drugs. Control groups (groups B and C) each consisted of 10 patients with primary open angle glaucoma for whom primary trabeculectomy (group B) or trabeculectomy following failure of topical beta-blockers alone (group C) was planned. Treatment with topical beta-blocker drugs was found to redistribute mast cells within the conjunctiva but to have no significant effect on cell numbers. In comparison with either control group, uveitic conjunctiva was found to contain significantly more fibroblasts, lymphocytes and macrophages. It is possible that these differences are responsible for an enhanced risk of excessive external bleb fibrosis, failure of filtration surgery and poor results with adjunctive 5-fluorouracil.
\end{abstract}

In selected patients with glaucoma, trabeculectomy is a highly successful surgical procedure for the control of intraocular pressure (IOP). A success rate of $98 \%$ has recently been reported in a group of patients with primary open angle glaucoma (POAG) treated by primary trabeculectomy. ${ }^{1}$ Certain groups of patients, however, do not fare so well; race,,$^{2-4}$ age, ${ }^{5}$ previous ocular surgery ${ }^{6-8}$ and secondary glaucoma ${ }^{9-11}$ are all risk factors associated with filtration failure.

In most patients who undergo successful filtration sur-

From: Moorfields Eye Hospital and the Department of Clinical Science, Institute of Ophthalmology, London, UK.

Correspondence to: David Broadway, Glaucoma Unit, Moorfields Eye Hospital, City Road, London EC1V 2PD, UK. gery, the conjunctiva forms a filtering bleb as draining aqueous accumulates in the subconjunctival space. Failure of filtration surgery is, in many cases, due to conjunctival fibroblast proliferation, collagen synthesis and subconjunctival fibrosis, resulting in bleb failure. ${ }^{12}$ In clinical practice such failure tends to occur either early (within the first few post-operative months) or late (often after several years). Early-onset failure is associated with a hypercellular response within the bleb, characterised by inflammation and an increase in the number of active fibroblasts. This contrasts with the findings in late-onset failure, which is characterised by blockage with fibrin and hypocellular fibrous tissue..$^{13}$ In patients with glaucoma secondary to uveitis, ocular inflammation is thought to enhance subconjunctival wound healing following filtration surgery and excessive wound healing increases the risk of bleb failure, which is usually early in onset. This may explain why the outcome of trabeculectomy in patients with uveitic glaucoma is poor. ${ }^{14-19}$ Although administration of subconjunctival 5-fluorouracil (5-FU), aimed at reducing post-operative wound healing, has been reported to be of use in certain high-risk cases ${ }^{20}$ our findings indicate that in patients with uveitis the benefits are negligible. ${ }^{21}$

The aim of this study was to compare the cellular content of the conjunctiva from patients with uveitic glaucoma with that of patients with POAG in order to determine whether any differences in the resident cell population of the conjunctiva and potential cellular mechanisms within the conjunctiva could explain the poor results of trabeculectomy and the poor response to 5-FU in these patients.

\section{PATIENTS AND METHODS}

\section{Patients}

Conjunctival biopsy specimens were obtained at the time of filtration surgery from 30 patients. with glaucoma attending Moorfields Eye Hospital, London. The patients 
Table I. Aetiology of the uveitic glaucoma

\begin{tabular}{ll}
\hline Anterior uveitis & \\
Unknown aetiology & 3 \\
Sarcoid & 1 \\
Juvenile arthritis & 1 \\
Posterior uveitis & \\
Unknown aetiology & 1 \\
Fuchs' heterochromia & 3 \\
Pars planitis & 1 \\
\hline
\end{tabular}

were subdivided into three groups depending on the cause of glaucoma and the regimen of medical therapy they had been treated with prior to surgery.

Group A, the uveitic group, consisted of 10 patients with uveitis and secondary glaucoma requiring trabeculectomy. Five of these patients had an anterior uveitis and 5 an intermediate or posterior uveitis (Table I). The demographic data for the patients in each of the three groups is summarised in Table II. The patients in each group were matched as closely as possible but despite selection of relatively young POAG patients, those in group A were significantly younger than those of either group B or group C. The patients had been treated for variable durations with topical steroids ( $0-8$ years) and topical beta-blocker ( 2 months -8 years) (Table II).

Group B, the primary surgery or control group, consisted of 10 patients with POAG who underwent planned primary trabeculectomy within 6 weeks of the diagnosis of glaucoma. These patients had been treated with topical medication for a maximum of only 6 weeks whilst waiting for surgery and were matched as closely as possible to the patients in group A (Table II).

In view of the growing evidence that previous topical antiglaucoma medications have an adverse effect on the conjunctiva $^{22}$ and outcome of filtration surgery ${ }^{23-25}$ a further control group was selected. Group C consisted of 10 patients with POAG who had been treated with a topical beta-blocker alone for a minimum of 2 months. These

Table II. Demographic data

\begin{tabular}{|c|c|c|c|}
\hline & Group A & Group B & Group C \\
\hline$n$ & 10 & 10 & 10 \\
\hline Diagnosis & Uveitis & POAG & POAG \\
\hline \multicolumn{4}{|l|}{ Age } \\
\hline Mean (years) & 40.6 & 53.4 & 53.1 \\
\hline Range & $23-76$ & $41-76$ & $31-74$ \\
\hline \multicolumn{4}{|l|}{ Race } \\
\hline White & 7 & 7 & 8 \\
\hline Non-white & 3 & 3 & 2 \\
\hline \multicolumn{4}{|l|}{ Sex } \\
\hline Male & 3 & 8 & 5 \\
\hline Female & 7 & 2 & 5 \\
\hline \multicolumn{4}{|l|}{ Eye } \\
\hline Right & 6 & 5 & 3 \\
\hline Left & 4 & 5 & 7 \\
\hline \multicolumn{4}{|l|}{ Topical anti-glaucoma therapy } \\
\hline Type & Beta-blocke & Pilocarpine & Beta-blocker \\
\hline Mean duration (months) & 18.8 & 0.6 & 17.9 \\
\hline Range & $2-96$ & $0-1.3$ & $2-89$ \\
\hline \multicolumn{4}{|l|}{ Topical steroid therapy } \\
\hline Mean duration (months) & 16.1 & 0 & 0 \\
\hline Range & 0-96 & & \\
\hline
\end{tabular}

POAG, primary open angle glaucoma. patients were matched as closely as possible with those in group A, in particular with respect to the duration of topical therapy (Table II).

None of the 30 patients had any additional ocular disease and none had undergone previous ocular surgery.

\section{Methods}

All patients underwent a Cairns type trabeculectomy with a Watson modification. ${ }^{26}$ Specimens of superior bulbar conjunctiva were obtained with minimal trauma from the nasal or temporal edge of the conjunctival flap at the time of surgery. Specimen size varied from about $1 \mathrm{~mm}^{3}$ to $5 \mathrm{~mm}^{3}$, smaller biopsies being taken when it was felt that larger specimens would compromise the outcome of surgery.

The biopsies were immediately fixed in $2.5 \%$ phosphate-buffered glutaraldehyde. After a minimum of 24 hours they were post-fixed in $1 \%$ buffered osmium tetroxide, dehydrated through graded alcohols and embedded in epoxy resin (Araldite, Agar Scientific, Stanstead, UK). Semi-thin sections $0.5 \mu \mathrm{m}$ thick were cut using an ultramicrotome (Reichert-Jung Ultracut E, Leica UK, Milton Keynes, UK) and stained with toluidine blue.

Light microscopic analysis of the specimens was performed using the $\times 100 / 1.25$, oil-immersion objective of a standard light microscope (Vickers Instruments, Dartford, UK) and $\times 10$ eyepieces fitted with an indexed squaregrating graticule (Agar Scientific, Stanstead, UK).

For each specimen the numbers of goblet cells, pale basal cells, lymphocytes, macrophages and intra-epithelial cysts were counted in the epithelial layer and the numbers of fibroblasts, macrophages, lymphocytes, plasma cells, mast cells and granulocytes were counted in the conjunctival substantia propria.

Cell counting and identification were established using rigid criteria. Cells were only counted when both nuclear and cytoplasmic morphology made clear identification of cell type possible. Within the epithelium, basal pale cells were counted. These include both melanocytes and Langerhans cells, which cannot be distinguished by toluidine blue staining. All intra-epithelial cysts were counted, most being hyaline body cysts. ${ }^{27}$ All counts were made in a masked fashion and some specimens were counted twice, enabling an intra-observer/sampling error to be determined. This error was $<10 \%$ for all cell types.

Cell counts were based on 20 field lengths of epithelium $(2 \mathrm{~mm})$ and 20 field areas $\left(0.2 \mathrm{~mm}^{2}\right)$ of subepithelial tissue. With all the specimens a count was made in the epithelium and superficial substantia propria (the most superficial $0.1 \mathrm{~mm}$ ). When possible a further count was made in deep substantia propria $(>0.1 \mathrm{~mm}$ from the epithelial basement membrane). With two specimens a deep count was not possible because of insufficient depth of biopsied tissue. In the majority of cases at least three or four sections per specimen had to be assessed in order to obtain an adequate area of conjunctiva for analysis. Therefore, sections were cut at a minimum of $20 \mu \mathrm{m}$ apart so as to provide a different population of cells on each section. 
a

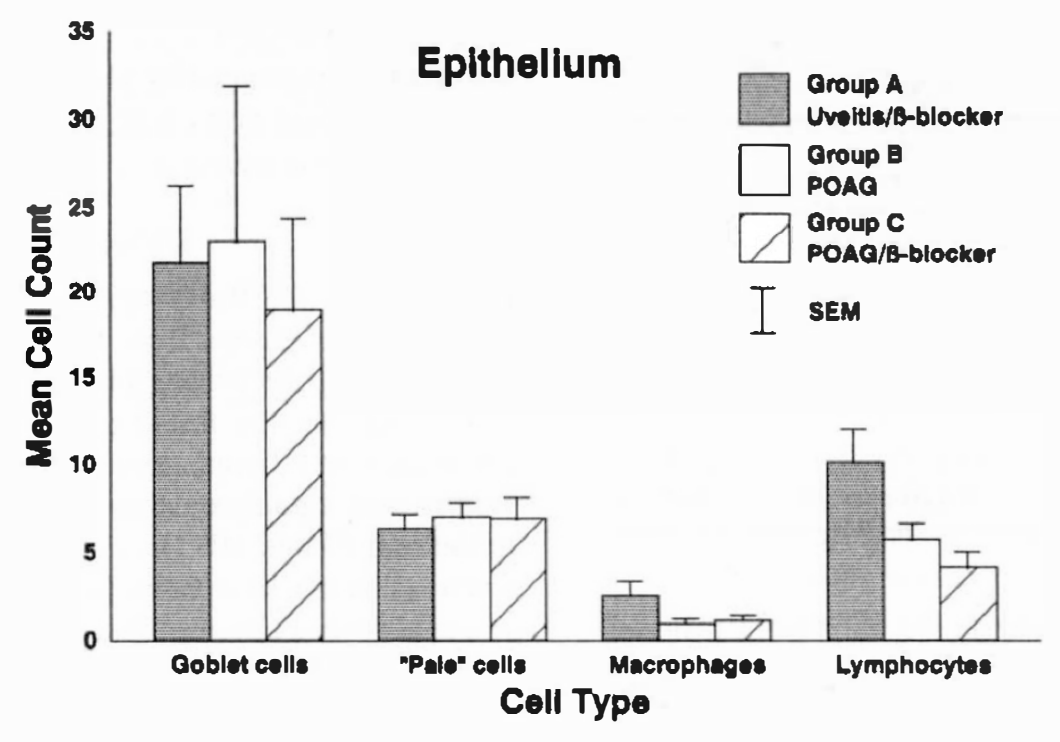

b
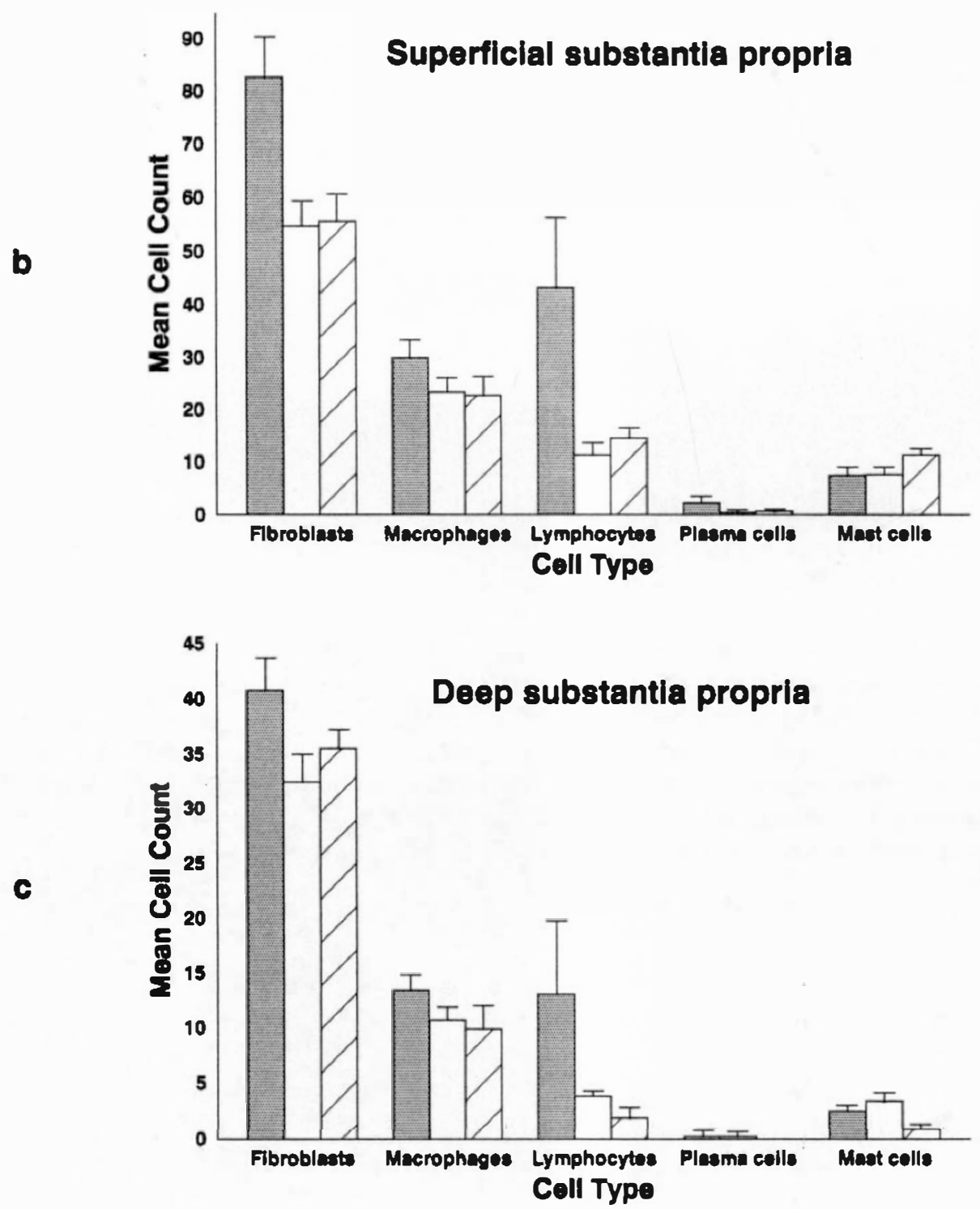

Fig. 1. Comparison of mean cell counts in the conjunctival epithelium (a) and in the superficial (b) and deep (c) substantia propria, between patients with glaucoma secondary to uveitis (group A) and patients with POAG, both untreated (group B) or treated with the same amount of topical beta-blocker as the patients in group A (groupC). SEM, standard error of the mean; POAG, primary open angle glaucoma. 
Table III. The significantly different cell counts in the comparison between uveitic conjunctiva (group A) and primary trabeculectomy control conjunctiva (group B) (mean \pm SEM)

\begin{tabular}{|c|c|c|c|}
\hline Cell type & $\begin{array}{l}\text { Uveitis } \\
\text { group (A) }\end{array}$ & $\begin{array}{c}1^{\circ} \text { trabeculectomy } \\
\text { group (B) }\end{array}$ & $p$-value ${ }^{\mathrm{a}}$ \\
\hline \multicolumn{4}{|l|}{ Epithelium } \\
\hline Macrophages & $2.5 \quad(0.5)$ & $0.9 \quad(0.2)$ & $<0.01$ \\
\hline \multicolumn{4}{|c|}{ Superficial substantia } \\
\hline Fibroblasts & 82.7 (7.4) & 54.7 (4.4) & $<0.02$ \\
\hline Lymphocytes & $43.2(12.9)$ & $11.3(1.8)$ & $<0.01$ \\
\hline \multicolumn{4}{|c|}{ Deep substantia } \\
\hline Fibroblasts & $40.8 \quad(2.8)$ & $32.4(2.5)$ & $<0.05$ \\
\hline Lymphocytes & $13.0 \quad(6.6)$ & $3.8(0.4)$ & $<0.05$ \\
\hline
\end{tabular}

${ }^{\text {a}}$ Mann-Whitney $U$-test.

The area of any vessels within the substantia propria, organised lymphocytic follicles or tissue artefacts within fields of assessment were determined for each observed field using the square-grating eyepiece graticule. An equivalent area of extravascular tissue was then assessed over and above the 20 field areas such that each cell count represented the number of cells in $0.2 \mathrm{~mm}^{2}$ of extravascular connective tissue. Thus, cells within vessels were not counted.

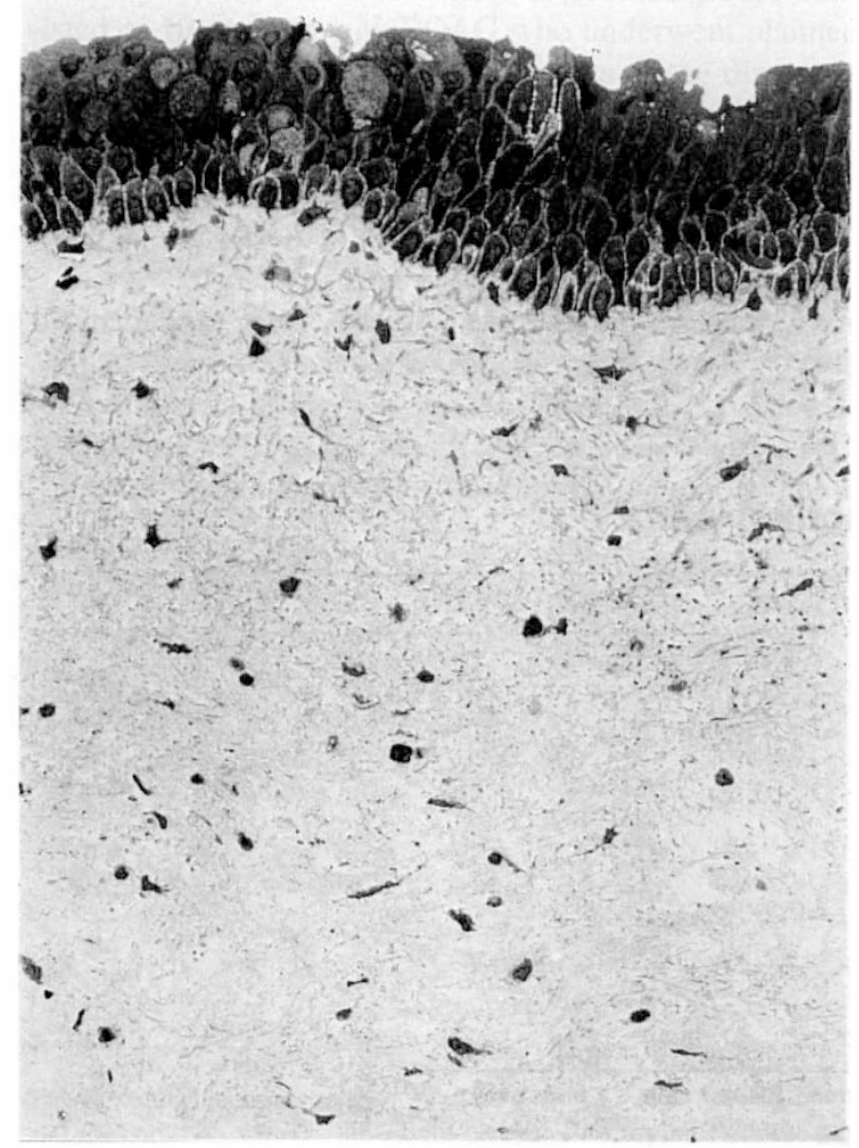

Fig. 2. A section of conjunctiva taken from a patient with primary open angle glaucoma who underwent a primary trabeculectomy. The epithelium is normal and the subepithelial tissue is relatively acellular. (Toluidine blue, original magnification $\times 550$.)

\section{Statistical Analysis}

Non-parametric statistics (Mann-Whitney $U$-test) were used to compare cell counts between the patient groups using the C-Stat statistical package (Oxtech, Oxford, UK).

\section{RESULTS}

Cell counts for the three regions of conjunctiva are shown in Fig. 1. In comparison with conjunctiva from the primary trabeculectomy group (group B) uveitic conjunctiva (group A) was found to contain significantly more fibroblasts and lymphocytes throughout the substantia propria and significantly more macrophages within the epithelium (Table III). Fig. 2 shows a section of conjunctiva taken from a patient with POAG who underwent a primary trabeculectomy. The subepithelial tissue is relatively acellular in comparison with that shown in Fig. 3 from a patient with glaucoma secondary to uveitis.

By comparing conjunctiva from the primary trabeculectomy group (group B) with that from patients treated with topical beta-blockers alone (group C) it was found that the use of topical beta-blockers had little effect on the cell populations apart from the numbers of mast cells in the substantia propria. From these counts it appears that topical beta-blockers reduce the number of deep mast cells

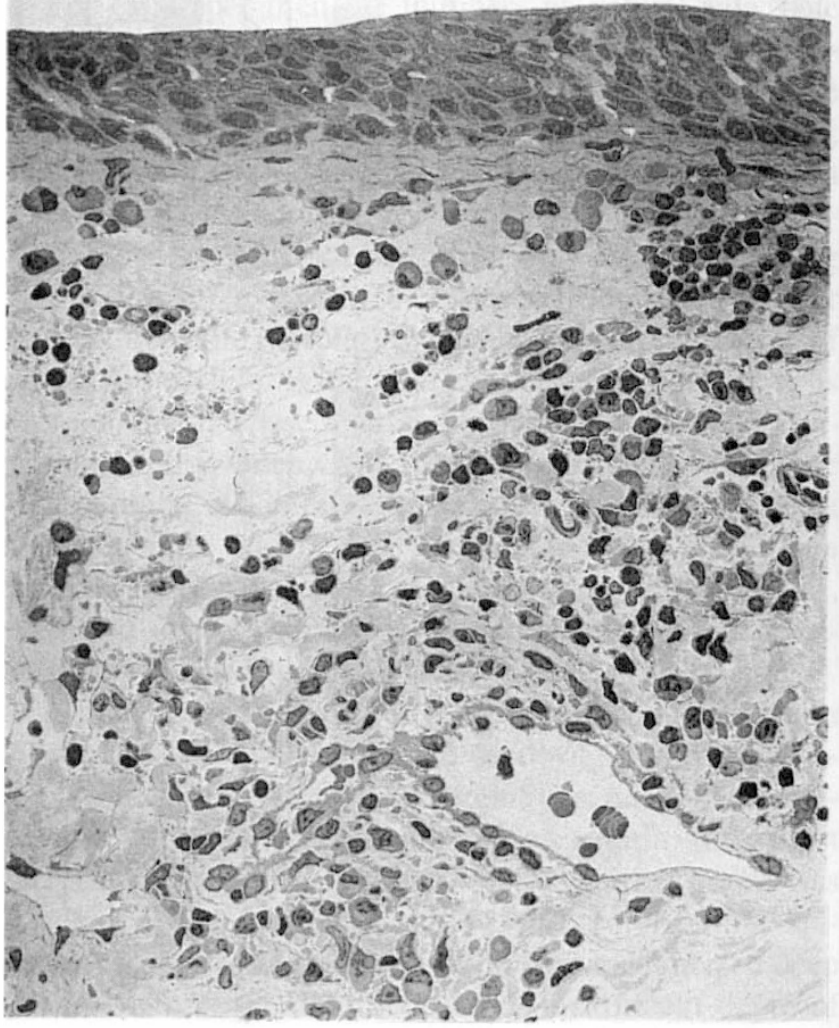

Fig. 3. A section of conjunctiva taken from a patient with glaucoma secondary to uveitis. The epithelium is normal but the subepithelial tissue is cellular, containing more fibroblasts and lymphocytes than control tissue (see Fig. 2). (Toluidine blue, original magnification $\times 550$.) 
Table IV. The significantly different cell counts in the comparison between primary trabeculectomy control conjunctiva (group B) and beta-blocker control conjunctiva (group C) (mean \pm SEM)

\begin{tabular}{|c|c|c|c|}
\hline Cell type & $\begin{array}{l}1^{\circ} \text { trabeculectomy } \\
\text { group }(\mathrm{B})\end{array}$ & $\begin{array}{l}\text { Beta-blocker } \\
\text { group }(\mathrm{C})\end{array}$ & $p$ value $^{\mathrm{a}}$ \\
\hline \multicolumn{4}{|c|}{ Superficial substantia } \\
\hline Mast cells & $7.5(1.4)$ & $11.3(0.8)$ & $<0.05$ \\
\hline $\begin{array}{l}\text { Deep substantia } \\
\text { Mast cells }\end{array}$ & $3.4(0.6)$ & $0.9(0.2)$ & $<0.01$ \\
\hline
\end{tabular}

"Mann-Whitney $U$-test.

and increase the number of superficial mast cells (Table IV).

Fig. 4 shows a section of conjunctiva taken from a patient with POAG treated with topical beta-blockers. A number of mast cells can be seen in the superficial substantia propria.

Since the effect of topical beta-blockers on most conjunctival cell numbers was insignificant a comparison between uveitic conjunctiva (group $\mathrm{A}$ ) and matched betablocker conjunctiva (group C) (Table V) was little different from that between uveitic conjunctiva (group A) and

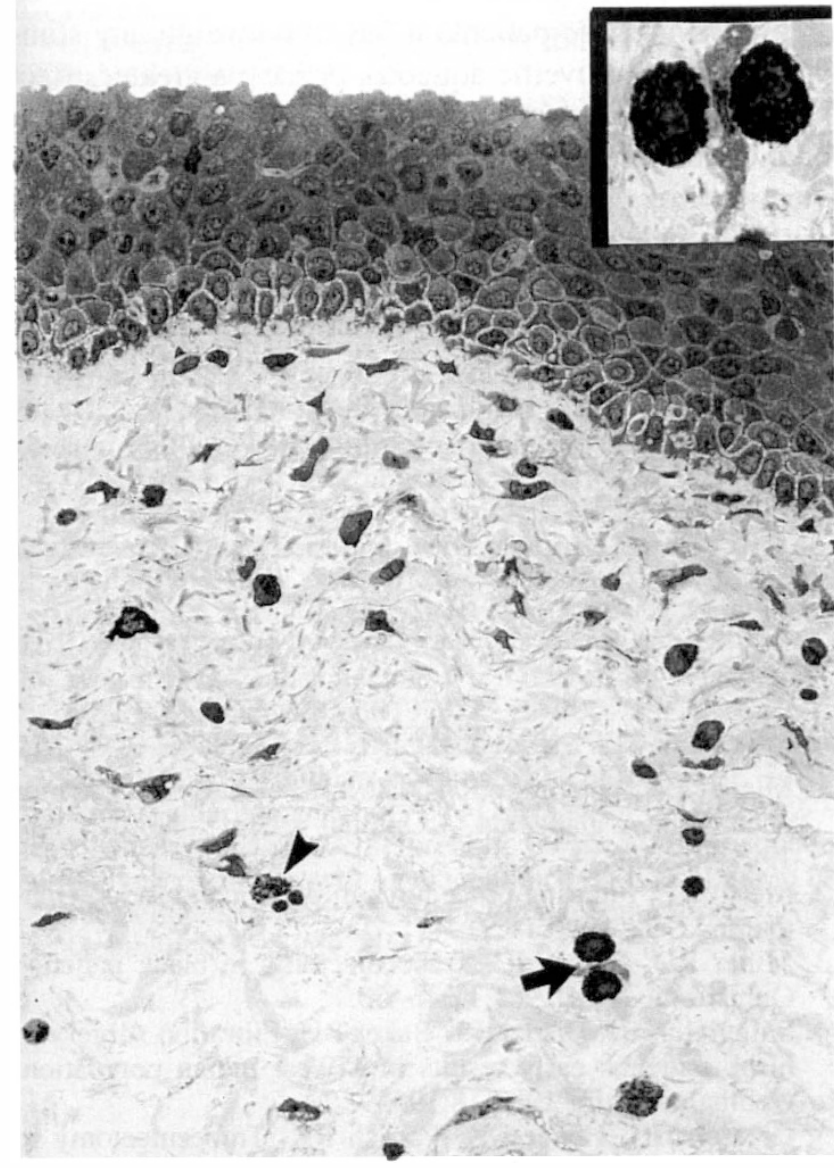

Fig. 4. A section of conjunctiva taken from a patient with primary open angle glaucoma treated with topical beta-blockers. The epithelium is normal and the subepithelial tissue relatively acellular. A number of mast cells are present in the superficial substantia propria (arrow; see also inset). A degranulating mast cell is also present in the superficial substantia propria (arrowhead). (Toluidine blue, original magnification $\times 550$ and $\times 1375$ [inset].) control conjunctiva (group B) (Table III). Again, uveitis was associated with an increased number of fibroblasts (in superficial, but not deep, substantia propria), lymphocytes (in all regions) and macrophages (within the epithelium). In addition uveitis was associated with an increased number of mast cells in the deep substantia propria.

\section{DISCUSSION}

Glaucoma secondary to uveitis is known to be a risk factor for failure of filtration surgery. ${ }^{14-19}$ The exact mechanism for this failure remains unknown, but since failure tends to be early in onset a stimulus for fibroblast proliferation is suspected. Herschler et al.$^{28}$ have shown that normal aqueous has an inhibitory effect on subconjunctival fibroblast proliferation and that in patients undergoing filtration surgery a positive relationship exists between surgical success and the fibroblast inhibitory activity of their aqueous. Intraocular inflammation with associated breakdown of the blood-aqueous barrier may result in aqueous with different properties from normal. Uveitic aqueous may thus contain factors which promote fibroblast proliferation, either directly or indirectly by inhibition of the normal inhibitory factor.

Since patients with glaucoma secondary to uveitis have invariably experienced chronic inflammation any abnormality of aqueous, or other extracellular ocular fluids, will be long standing by the time filtration surgery is required. Fibroblast proliferation may thus have been stimulated for some time prior to surgery. Our findings agree with such a hypothesis, in that the number of fibroblasts present in uveitic conjunctiva is significantly higher than in 'normal' conjunctiva. An increase in the population of resident fibroblasts at the time of filtration surgery may result in an exaggerated wound healing response in the post-operative period and explain, at least partially, the relatively high failure rate of trabeculectomy in patients with glaucoma secondary to uveitis.

The increase in number of fibroblasts may not be due to a direct effect of any aqueous-borne factor alone. A more complex series of cellular interactions is probably involved. Our results have shown that in addition to fibroblasts, the number of lymphocytes is also significantly increased in uveitic conjunctiva. This increase may be

Table V. The significantly different cell counts in the comparison between uveitic conjunctiva (group A) and beta-blocker control conjunctiva (group $\mathrm{C}$ ) (mean $\pm \mathrm{SEM})$

\begin{tabular}{lrcc}
\hline Cell type & $\begin{array}{c}\text { Uveitis } \\
\text { group (A) }\end{array}$ & $\begin{array}{c}\text { Beta-blocker } \\
\text { group (C) }\end{array}$ & $p$ value \\
\hline $\begin{array}{l}\text { Epithelium } \\
\text { Macrophages }\end{array}$ & $2.5(0.5)$ & $1.1(0.3)$ & $<0.05$ \\
$\begin{array}{l}\text { Lymphocytes } \\
\text { Superficial substantia }\end{array}$ & $10.1(1.9)$ & $4.1(0.8)$ & $<0.01$ \\
$\begin{array}{l}\text { Fibroblasts } \\
\text { Lymphocytes }\end{array}$ & $82.7(7.4)$ & $55.6(4.8)$ & $<0.01$ \\
$\begin{array}{l}\text { Deep substantia } \\
\text { Lymphocytes }\end{array}$ & $13.0(12.9)$ & $14.5(1.6)$ & $<0.01$ \\
Mast cells & $2.5(0.5)$ & $1.9(0.8)$ & $<0.01$ \\
\hline
\end{tabular}

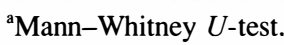


induced by an aqueous-borne factor, or alternatively may be a primary feature of the uveitic disease process. The increase in number of fibroblasts may occur secondary to the increase in lymphocyte numbers.

T-lymphocytes are known to participate in wound healing. In the early phase of healing there is dynamic infiltration of both $\mathrm{T}$ helper/effector and $\mathrm{T}$ suppressor/ cytotoxic lymphocytes into the superficial areas of a wound.$^{29}$ Indirect evidence that these cells play an active role, rather than a passive role in part of a generalised inflammatory cell infiltration, has been provided by in vivo studies: agents which stimulate lymphocytes, such as growth hormone, vitamin A and interleukin-2 (IL-2), have been shown to increase collagen deposition and wound breaking strength, whereas agents that inhibit lymphocyte function, such as steroid, cyclosporin A and retinoic acid, reduce fibrosis. ${ }^{30}$ The main role of the T-lymphocyte in wound healing appears to be as a moderating or controlling cell, since the process can be initiated and completed in the absence of T-lymphocytes, albeit less effectively ${ }^{30,31}$ There is also evidence that different T-lymphocyte subsets have differing effects on wound healing. ${ }^{32}$ Under normal circumstances, stimulatory and inhibitory T-lymphocyte effects on wound cellular activity are well balanced and it may be an imbalance in this control which is responsible for the excessive fibrosis in patients with uveitic glaucoma undergoing filtration surgery. Activated T-lymphocytes are able to induce recruitment, proliferation and activation of fibroblasts. ${ }^{33}$ This control may occur via lymphokines acting directly on fibroblasts. In vitro studies have shown that various lymphokines can either stimulate (e.g. transforming growth factor- $\beta$ (TGF- $\beta$ ), fibroblast activating factor) or inhibit (e.g. alpha and gamma interferon, fibroblast inhibitory factor) fibroblast activity in terms of proliferation, chemotaxis and collagen synthesis. ${ }^{33}$ In vivo studies have provided further evidence, and in animal models TGF- $\beta$ has been shown to increase granulation tissue formation, collagen deposition and wound breaking strength. ${ }^{34-36}$ TGF- $\beta$ is considered to be one of the most potent stimuli of fibroblast synthetic activity. ${ }^{37}$ Relative overproduction of stimulatory lymphokines such as TGF- $\beta$ may be the cause of excessive fibrosis in patients with uveitic glaucoma.

Alternatively T-lymphocytes may stimulate fibroblasts by an indirect effect on other cells, such as macrophages. In support of this is the fact that lymphokines can trigger the release of macrophage-derived fibrogenic cytokines. ${ }^{38}$ Although only significant in the conjunctival epithelium, our results have shown a tendency for uveitic conjunctiva to contain more macrophages than control tissue. The number of cells, however, is not the only crucial factor and the degree of cellular activation is equally, if not more important. Indeed, resident macrophages are suppressive of fibroblast function, while activated macrophages are stimulatory. ${ }^{31}$ Macrophages play a key role in wound healing by phagocytosis (removal of damaged and exogenous material), generation of chemotactic factors which recruit inflammatory cells, production of cytokines and accumu- lation and proliferation of fibroblasts and endothelial cells. ${ }^{39,40}$ Macrophages are thought to be a principal source of fibrogenic cytokines such as platelet-derived growth factor, tumour necrosis factor, TGF- $\alpha$ and TGF- $\beta,{ }^{40-43}$ so that activation of such cells is critical for normal wound healing and amplified macrophage activity may result in excessive wound healing.

More work is required to determine the degree of activation of the various cell populations. It is, however, proposed that in patients with glaucoma secondary to uveitis the wound healing response is up-regulated by an increase in the number and degree of activation of inflammatory cells (especially lymphocytes and macrophages), which in turn increases the number and activity of fibroblasts. The response may be achieved by a direct effect of lymphokines, indirectly via the mediation of macrophages, or by both pathways.

Our results suggest that cellular changes in the conjunctiva of patients with glaucoma secondary to uveitis may be partly responsible for the poor results of trabeculectomy. In addition they may explain the poor response to post-operative subconjunctival injections of 5-FU. 5-FU inhibits fibroblast proliferation ${ }^{44}$ and for its effect to be significant in these patients it has to outweigh any stimulatory effect of uveitic aqueous, or have a greater effect due to the higher number of resident fibroblasts and inflammatory cells. Further studies are required to determine whether changes in the peri-operative management of these patients, aimed at a conjunctival level, can improve success rates. In view of the potential importance of conjunctival lymphocytes and other inflammatory cells in these patients, peri-operative treatment with systemic steroids, or other immunosuppressive agents such as cyclosporin, in addition to topical steroids may prove useful.

The T.F.C. Frost Charitable Trust supported David Broadway in this study.

Key words: Conjunctiva, Secondary glaucoma, Trabeculectomy, Uveitis, Wound healing.

\section{REFERENCES}

1. Migdal CS, Hitchings RA. The role of early surgery for open-angle glaucoma. Ophthal Clin North Am 1991;4:853-9.

2. Merritt JC. Filtering procedures in American blacks. Ophthalmic Surg 1980;11:91-4.

3. Miller RD, Barber JC. Trabeculectomy in black patients. Ophthalmic Surg 1981;12:46-50.

4. Shingleton BJ, Distler JA, Baker BH. Filtration surgery in black patients: early results in a West Indian population. Ophthalmic Surg 1987;18:195-9.

5. Gressel MG, Heuer DK, Parrish RK. Trabeculectomy in young patients. Ophthalmology 1984;91:12424-6.

6. Herschler J. Medically uncontrolled glaucoma in the aphakic eye. Ann Ophthalmol 1981;13:909.

7. Inaba Z. Long-term results of trabeculectomy in the Japanese: an analysis by life-table method. Jpn J Ophthalmol 1982;26:361-73.

8. Heuer DK, Gressel MG, Parrish RK, Anderson DR, Hodapp E, Palmberg PF. Trabeculectomy in aphakic eyes. Ophthalmology 1984;91:1045-51. 
9. Mills KB. Trabeculectomy: a retrospective long-term follow-up of 444 cases. Br J Ophthalmol 1981;65:790-5.

10. Allen RC, Bellows AR, Hutchinson BT, Murphy SD. Filtration surgery in the treatment of neovascular glaucoma. Ophthalmology 1982;89:1181-7.

11. Katz LJ, Spaeth GL. Surgical management of the secondary glaucomas: I. Ophthalmic Surg 1987;18:826-34.

12. Skuta L, Parrish RK. Wound healing in glaucoma filtering surgery. Surv Ophthalmol 1987;32:149-70.

13. Hitchings RA, Grierson I. Clinicopathological correlation in eyes with failed fistulizing surgery. Trans Ophthalmol Soc UK 1983;103:84-8.

14. Hoskins HD, Hetherington J Jr, Shaffer RN. Surgical management of the inflammatory glaucomas. Perspect Ophthalmol 1977;1:173-81.

15. Watson PG, Grierson I. The place of trabeculectomy in the treatment of glaucoma. Ophthalmology 1981;88:175-96.

16. Kanski JJ, Shun-Shin GA. Systemic uveitis syndromes in childhood: an analysis of 340 cases. Ophthalmology 1984;91:1247-51.

17. Kanski JJ, McAllister JA. Trabeculodialysis for inflammatory glaucoma in children and young adults. Ophthalmology 1985;92:927-30.

18. Epstein DL. Glaucoma due to intraocular inflammation. In: Epstein DL, editor. Chandler and Grant's glaucoma. Philadelphia: Lea and Febiger, 1986:352-77.

19. Jones NP. Glaucoma in Fuchs' heterochromic uveitis: aetiology, management and outcome. Eye 1991;5:662-7.

20. The Fluorouracil Filtering Surgery Study Group. Fluorouracil filtering surgery study: one-year follow-up. Am J Ophthalmol 1989;108:625-35.

21. Bates AK, Broadway DC, Lightman SL, Hitchings RA. Trabeculectomy with 5-fluorouracil for glaucoma secondary to uveitis. Eye 1993 (in preparation).

22. Sherwood MB, Grierson I, Millar L, Hitchings RA. Longterm morphologic effects of antiglaucoma drugs on the conjunctiva and Tenon's capsule in glaucomatous patients. Ophthalmology 1989;96:327-35.

23. Lavin MJ, Wormald RPL, Migdal CS, Hitchings RA. The influence of prior therapy on the success of trabeculectomy. Arch Ophthalmol 1990;108:1543-8.

24. Longstaff S, Wormald RPL, Mazover A, Hitchings RA. Glaucoma triple procedures: efficacy of intraocular pressure control and visual outcome. Ophthalmic Surg 1990;21:786-93.

25. Miller MH, Rice NSC. Trabeculectomy combined with $\beta$ irradiation for congenital glaucoma. $\mathrm{Br} \mathrm{J}$ Ophthalmol 1991;75:584-90.

26. Watson PG. Trabeculectomy: a modified ab externo technique. Ann Ophthalmol 1970;2:199-206.

27. Abdel-Khalek LMR, Williamson J, Lee WR. Morphological changes in the human conjunctival epithelium. I. In the normal elderly population. Br J Ophthalmol 1978;62:792-9.

28. Herschler J, Claflin AJ, Fiorentino G. The effect of aqueous humour on the growth of subconjunctival fibroblasts in tissue culture and its implications for glaucoma surgery. Am J Ophthalmol 1980;89:245-9.
29. Fishel RS, Barbul A, Beschorner WE, Wasserkrug HI, Efron G. Lymphocyte participation in wound healing: morphologic assessment using monoclonal antibodies. Ann Surg 1987;206:25-9.

30. Barbul A. Role of the T cell-dependent immune system in wound healing. Prog Clin Biol Res 1988;266:161-75.

31. Regan MC, Barbul A. Regulation of wound healing by the $T$ cell-dependent immune system. In: Janssen H, Rooman R, Robertson JIS, editors. Wound healing. Petersfield: Wrightson Biomedical, 1991:21-31.

32. Barbul A, Breslin RJ, Woodyard JP, et al. The effect of in vivo $\mathrm{T}$ helper and $\mathrm{T}$ suppressor lymphocyte depletion on wound healing. Ann Surg 1989;209:479-83.

33. Wahl SM, Allen JB. T lymphocyte-dependent mechanisms of fibrosis. Prog Clin Biol Res 1988;266:147-60.

34. Roberts AB, Sporn MB, Assoian RK, et al. Transforming growth factor type $\beta$ : rapid induction of fibrosis and angiogenesis in vivo and stimulation of collagen formation in vitro. Proc Natl Acad Sci USA 1986;83:4167-71.

35. Mustoe TA, Pierce GF, Thomason A, Gramates P, Sporn MB, Deuel TF. Accelerated wound healing of incisional wounds in rats by transforming growth factor- $\beta$. Science 1987;237:1333-8.

36. Pierce GF, Mustoe TA. Lingelbach J, Masakowski VR, Gramates P, Deuel TF. Transforming growth factor- $\beta$ reverses the glucocorticoid-induced wound-healing deficit in rats: possible regulation in macrophages by plateletderived growth factor. Proc Natl Acad Sci USA 1989; 86:2229-33.

37. Sporn MB, Roberts AB, Wakefield LM, de Crombrugghe B. Some recent advances in the chemistry and biology of transforming growth factor-beta. J Cell Biol 1987;105:1039-45.

38. Kovacs EJ, Kelley J. Lymphokine regulation of macrophage-derived growth factor secretion following pulmonary injury. Am J Pathol 1985;121:261-8.

39. Leibovich SJ, Ross R. The role of the macrophage in wound repair: a study with hydrocortisone and antimacrophage serum. Am J Pathol 1975;78:71-91.

40. Wong H, Wahl S. Inflammation and repair. In: Sporn M, Roberts A, editors. Handbook of experimental pharmacology, vol 95/II, Peptide growth factors and their receptors II. Berlin: Springer-Verlag, 1990:509-48.

41. Rapolee DA, Mark D, Banda MJ, Werb Z. Wound macrophages express TGF- $\alpha$ and other growth factors in vivo: analysis by mRNA phenotyping. Science 1988;241:708-12.

42. Piguet PF, Collart MA, Grau GE, Sappino A-P, Vassalli P. Requirement of tumour necrosis factor for development of silica-induced pulmonary fibrosis. Nature 1990;344:245-7.

43. Madtes DK, Raines EW, Sakariassen KS, et al. Induction of transforming growth factor- $\alpha$ in activated human alveolar macrophages. Cell 1988;53:285-93.

44. Blumenkranz MS, Claflin A, Hajek AS. Selection of therapeutic agents for intraocular proliferative disease: cell culture evaluation. Arch Ophthalmol 1984;102:598-604. 